\title{
JOURNAL OF THE MARINE BIOLOGICAL ASSOCIATION
}

\section{INSTRUCTIONS FOR THE PREPARATION OF MANUSCRIPTS}

\section{Editorial Policy}

The $J M B A$ publishes papers on all aspects of marine biology and oceanography. Papers should report the results of original research and must not have been published, or be under consideration for publication, elsewhere.

\section{General}

Papers should be written in English and should be as clear and succinct as possible. If there is a particular reason why rapid publication is desirable this should be stated with the submission. If acronyms are used they must be specified in full on their first occurrence. SI units should be used. Sentences must not start with an abbreviation. Only the scientific names of species should be italicized, and their first mention should be followed by the authority except where reference is made to a work in which the authority appears. Footnotes must not be used.

A total of three copies of the typescript should be provided, double-spaced throughout, on one side of A4 paper. Tables, and legends for illustrations should be typed separately at the end of the manuscript. All pages should be numbered serially (title, main text, acknowledgements, references, figure legends, tables). The originals and two copies of the illustrations should be provided. Whenever possible a copy of the text, once the paper has been accepted, should also be provided on a floppy disc (see below).

Short communications, which may also report on new methods or techniques, should not exceed four printed pages, including tables and illustrations. These papers must start with an abstract but are not otherwise divided into sections.

Page proofs only will be sent. One hundred reprints will be provided free of charge and up to 200 extra copies may be purchased if ordered when the proofs are returned.

\section{Title}

Each paper must have a unique title and not be one of a numbered series. The title should be kept as short as possible (maximum 18 words), and if specific names are included the authority should be omitted. A running head of not more than 43 characters should be suggested.

\begin{abstract}
Each paper (including short communications) must start with a brief abstract summarizing the main results and conclusions of the work, and such other information as make it suitable for publication without change in abstracting journals. No references should be given in the abstract. If the title includes specific names, the abstract must include the taxonomic group to which the species belongs (e.g. Pholoe minuta (Annelida: Polychaeta)). The abstract must be intelligible to a reader who is not a specialist in the subject of the paper.
\end{abstract}

\section{References}

References should be kept to an essential minimum and must be listed alphabetically at the end of the paper. Care should be taken to ensure that all those quoted in the text are included, but no others. The full title of the paper and all the authors must be given. Where a volume appears in parts the part need be specified only where each has separate pagination. Titles of journals are given in full and references to books should include the place of publication and publisher. Citations in the text to be given as 'Smith \& Jones (1964)', or '(Smith \& Jones, 1964)', or 'Smith et al. (1964)' if there are more than two authors, except where this is ambiguous.

Examples:

Goldberg, E.D., 1965. Minor elements in sea water. In Chemical oceanography, vol. 1 (ed. J.P. Riley and G. Skirrow), pp. 163-196. New York: Academic Press.

Marshall, S.M., Nicholls, A.G. \& Orr, A.P., 1939. On the growth and feeding of young herring in the Clyde. Journal of the Marine Biological Association of the United Kingdom, 23, 427-455.

Russell, F.S. \& Yonge, C.M., 1928. The seas. London: Frederick Warne. 


\section{JOURNAL OF THE MARINE BIOLOGICAL ASSOCIATION}

\section{Figures}

Figures should be in black ink on white paper no larger than A4, and must be suitable for reproduction. Figures will normally be reduced as much as possible to save space (to one-third of a page on average), and the lines and lettering should be of a suitable size and thickness. After reduction the maximum size for a figure or photograph is $134 \times 200 \mathrm{~mm}$, including legend. Lettering, numerals etc. should conform to JMBA style (Helvetica 8 point after reduction). Symbols should be kept to a minimum and must be clearly explained in the legend.

Half-tone photographs will be reproduced in the text pages and should be supplied as glossy prints with suitable labelling on the originals. Sizes should be indicated by a scale line on the print (parallel to the side or bottom) and not by a magnification factor in the legend. Three sets of glossy prints are required.

Legends for figures must be typed all together on a separate sheet. All illustrations, including photographs, are numbered in Arabic numerals and referred to in the text as 'Figure 1', etc. Where a figure comprises two or more distinct components they must be given a single Figure number and be distinguished by capital letters (e.g. Figure 1A).

Please ensure that multiple diagrams are lined up correctly, with as little space between parts as possible, and labelled 'A', 'B', etc. If graphs have been plotted using a computer package the scales must be labelled in sensible intervals.

Coloured illustrations can be included but only at the author's expense (about $£ 1000$ per page).

\section{Tables}

Tables should be numbered in Arabic numerals, and given a concise heading.

\section{Word-processor discs}

All manuscripts should be provided on a floppy disc after the paper has been accepted. It is not necessary to send the disc when submitting the paper initially, as it will almost certainly need revision after refereeing.

It will speed the publication of your paper if you can send a copy of the text on a Macintosh or IBM-type disc; 3.5-inch discs are preferred, but 5.25-inch double density (but not high density) are also acceptable. The disc will be returned to you.

If you are unable to provide an appropriate disc please ensure that the typescript is clearly printed.

\section{Please follow these instructions exactly:}

1. Ensure that the disc you send contains only the final version of the paper, with the whole text and all the tables in a single file, and is identical to the typescript.

2. Label the disc with author's name, title of paper, machine and word-processing package used.

3. If you have used a common PC or Macintosh word-processing programme send the file as a fully-formatted document.

4. Use italics not underlining for specific names etc. Make sure you distinguish numerals from letters, e.g. zero (0) from $\mathrm{O}$; one (1) from $\mathrm{l}$ and $\mathrm{I}$.

5. Type names of authors in the reference list in lower case, except for the initial letter.

6. Tables must also be included as computer files, preferably in the same file as the text. If they have been prepared using a different package then include them all in one file. If they are too wide to print directly then please include the basic data in one or more separate files, which we can use to make up the complete Table.

Authors are requested to see that their manuscripts are in finished form and completely ready for publication so that corrections may be reduced to a minimum. Alterations to the text at the proof stage will be charged to the author. 


\section{Go to sea with Springer}

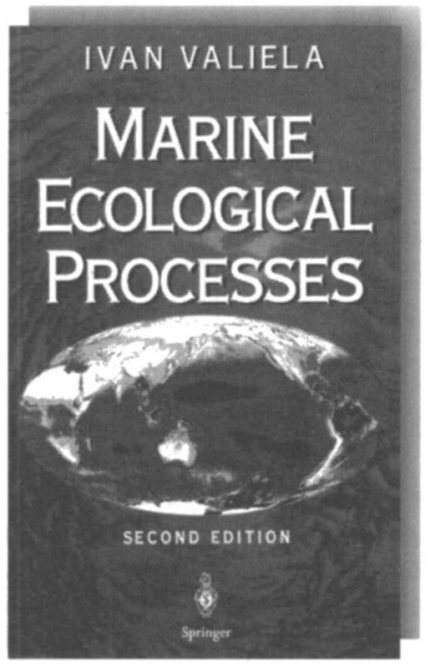

\section{Valiela \\ Marine Ecological Processes}

2nd edition 1995. XIV, 686 pages. 325 figures, 50 tables.

Hardcover DM 98,- ISBN 3-540-94321-8

Comprehensive in its coverage, this book focuses on the processes controlling marine ecosystems, communities and populations.

It demonstrates how general ecological principles apply to the oceans. Numerous illustrations, examples and references clearly impart the current state of knowledge in this field.

From the reviews of the first edition:

"... offers much as a textbook ... would-be marine ecologists would be well served by reading it"

- Science

“... invaluable for graduate students and professional marine biologists ... has no equal and will have no competitor for some time to come"
P. M. Vitousek, L. L. Loope, H. Adsersen (Eds.)

\section{Islands}

Biological Diversity and Ecosystems Function 1995. XVII, 238 pages. 17 figures

(Ecological Studies, Vol. 115).

Hardcover DM 168.- ISBN 3-540-57947-8

The volume addresses the components of biological diversity on islands and their patterns of variation: the modern threats to the maintenance of biological diversity; the consequences of island biology and its modification by humanity regarding aspects of ecosystem function; the global implications for conservation; and how islands can help one to understand the processes inducing changes throughout the worid.
H. (J.) G. Baretta-Bekker, E. K. Duursma, B. R. Kuipers (Eds.)

\section{Encyclopedia of Marine Sciences}

1st edition 1992. 2nd printing 1995

VIII, 311 pages. 127 figures.

Softcover DM 61,- $\quad$ ISBN 3-540-54501-8

The multidisciplinary character of this encyclopedia of marine sciences (Biology, Chemistry, Geology, Physics in Oceanography) is presented in 3000 up-to-date, alphabetically listed keywords, and many illustrations, which give scientists, teachers, and students a helpful and time-saving aid when studying marine scientific literature.
Prices are subject to change without notice. In EU countries the local WT is effective. 


\section{European Journal of Phycology}

\section{Editor-in-Chief}

Christine A. Maggs

\section{European Journal of Phycology}

The European Journal of Phycology has superseded the British Phycological Journal as one of the main journals in the field. Now published in a larger format and a new design, the Journal is becoming the natural focus for the activities of phycologists all over the world, especially in Europe. Particular emphasis is placed on high quality reproduction, especially for half tones.

European Journal of Phycology is published quarterly in February, May, August and November, and publishes papers on all aspects of the ecology, physiology, biochemistry, cell biology, molecular biology and systematics of algae (induding cyanobacteria). Papers dealing with applied aspects of phycology are equally welcome.

\section{EJP publishes ...}

Articles which may be in the form of Research Reports, or Miniviews - short articles which present the author's viewpoint on important recent developments in or reviews of significant articles. Porential contributors of miniviews are invited to consult the appropriate Associate Editor before preparing a submission.

All manuscripts are subject to multiple peer review before publication.

Manuscripts should be submitted in triplicate to the appropriate Associate Editor.

\section{Editors}

In order to ensure that the European Journal of Phycology meets the highest of professional academic standards and in order to guarantee expertise in all of the areas covered by the journal, the Editor-in-Chief, Christine Maggs is assisted by a team of eight associate editors who are experts in particular aspects of the subject (macroalgal ecology, microalgal ecology, physiology \& biochemistry, cell biology, molecular biology, macroalgal systematics, microalgal systematics, applied phycology \& biotechnology).

\section{Subscription Information}

The European Journalof Phycology (ISSN 0967-0262) is published quarterly in February, May, August and November. Volume 10 in 1995 costs 6115 per year; airmail 12.50 per year extra.

\section{Take a closer look}

Please send me further information about European Journal of Phycology

Name

Address

|

Send this coupon to: Journals Marketing Department, Cambridge University Press, FREEPOST*, The Edinburgh Building, Shaftesbury Road, Cambridge, CB2 1BR, UK. Tel: +44 (0) 1223312393 Fax: 44 (0) 1223315052 *No stamp needed if posted in the UK In USA, Canada \& Mexico write to: Cambridge University Press, 40 West 20th Street, New York, NY 10011 4211, USA 
Cover: The photograph on the outside of the cover was taken by David Nicholson at Pedney Beach, Cornwall

(C) 1995 Marine Biological Association of the United Kingdom (Registered charity no. 226063) 


\section{JMBA}

JOURNAL OF THE MARINE BIOLOGICAL ASSOCIATION OF THE UNITED KINGDOM

VOLUME 75:4 NOVEMBER 1995

\section{CONTENTS}

\section{PAGE}

Jordan, R. W., Kleijne, A., Heimdal, B. R. \& Green, J. C. A glossary of the extant Haptophyta of the world

Stoecker, D. K., Putt, M. \& Moisan, T. Nano- and microplankton dynamics during the spring Phaeocystis sp. bloom in McMurdo Sound, Antarctica

Beja, P. R. Structure and seasonal fluctuations of rocky littoral fish assemblages in southwestern Portugal: implications for otter prey availability

Priede, I. G., Raid, T. \& Watson, J. J. Deep-water spawning of Atlantic mackerel Scomber scombrus, west of Ireland

Brey, T., Peck, L. S., Gutt, J., Hain, S. \& Arntz, W. E. Population dynamics of Magellania fragilis, a brachiopod dominating a mixed-bottom macrobenthic assemblage on the Antarctic shelf

Caron, A., Boucher, L., Desrosiers, G. \& Retière, C. Population dynamics of the polychaete Nephtys caeca in an intertidal estuarine environment (Quebec, Canada)

Semmens, J. M., Moltschaniwskyj, N. A. \& Alexander, C. G. Effect of feeding on the structure of the digestive gland of the tropical sepioid Idiosepius pygmaeus

Kikinger, R. \& Salvini-Plawen, L.v. Development from polyp to stauromedusa in Stylocoronella (Cnidaria: Scyphozoa)

Curtis, L. A. Growth, trematode parasitism, and longevity of a long-lived marine gastropod (IIyanassa obsoleta)

Heuch, P. A. Experimental evidence for aggregation of salmon louse copepodids (Lepeophtheirus salmonis) in step salinity gradients

Kato, M. \& Itani, G. Commensalism of a bivalve, Peregrinamor ohshimai, with a thalassinidean burrowing shrimp, Upogebia major

Paxton, H., Fadlaoui, S. \& Lechapt, J.-P. Diopatra marocensis, a new brooding species of Onuphidae (Annelida: Polychaeta)

Fadlaoui, S., Lechapt, J.-P. \& Retière, C. Larval development of the onuphid Diopatra marocensis (Annelida: Polychaeta) from the Atlantic coast of Morocco

Piertney, S. B. \& Carvalho, G. R. Detection of high levels of genetic relatedness in rockpopulations of an intertidal isopod using DNA fingerprinting

Tyler, P. A., Paterson, G. J. L., Sibuet, M., Guille, A., Murton, B. J. \& Segonzac, M. A new genus of ophiuroid (Echinodermata: Ophiuroidea) from hydrothermal mounds along the midAtlantic ridge

Magorrian, B. H., Service, M. \& Clarke, W. An acoustic bottom classification survey of Strangford Lough, Northern Ireland

Short Communications:

Meldrum, F. C., Heywood, B. R., Dickson, D. P. E. \& Mann, S.

Spicer, J. I. \& Morritt, D. 